\title{
Predicting the Virtual Financial Communication Content: A Discriminant Analysis Applied on Small and Medium Stocks
}

\author{
Youssef Saida ${ }^{1}$ \\ ${ }^{1}$ ESCA Ecole de Management, Casablanca, Morocco \\ Correspondence: Youssef Saida, ESCA Ecole de Management, Casablanca, 7, Rue Abou Youssef El Kindy, Bd. \\ Mly Youssef 20 070, Casablanca, Morocco. E-mail: y.saida@yahoo.fr
}

Received: May 16, 2018

Accepted: September 2, 2018

Online Published: October 12, 2018

doi:10.5539/ijbm.v13n11p156

URL: https://doi.org/10.5539/ijbm.v13n11p156

\begin{abstract}
In competitive environment, information is an important aspect of organization management. In fact, information supports decision making process, improves operational activities, and enhances organizational effectiveness and governance. Therefore, information should be communicated effectively to specific stakeholders throughout an extremely well-integrated system. Financial information system is an important component of the information system. It aims to provide reliable financial information regarding firms listed in stock market. In this case, financial information is viewed as a main ingredient of virtual financial communication. This research aims to provide more insights about financial information provided by financial information system. Indeed, the study tries to explain to what extend financial information could predict the virtual financial communication content. The sample contains 64 organizations listed on the Casablanca stock exchange. A content analysis of websites and financial statements analysis are used for each company. Based on virtual financial communication content, two groups are constructed. We use three financial indicators for measuring the performance of these two groups. The discriminant analysis shows to what extend specific financial indicators could predict the virtual financial communication content. As results, these indicators show different levels of ability to predict virtual financial communication content. Our findings, when confronted to the literature, explicit convergences about the predictability of on-line corporate disclosure.
\end{abstract}

Keywords: financial information system, financial information, financial communication, stakeholders, performance, discriminant analysis

\section{Introduction}

Modern organization has to interact and communicate successfully with its different stakeholders. This communication is supported throughout a well-matched information system in order to satisfy specific stakeholders' objectives. This communication is vital to organizations listed in financial market. Public limited companies by law have to communicate on behalf the financial information. With different forms, financial information is regulary communicated to stakeholders (CEOs, shareholders, investors, regulators, etc.).

Financial communication is mainly based on accounting information system. In fact, financial information provides visibility and transparency about organization's assets, performance, risks and businesses. It is necessary to have an information system responsible for collecting, storing and reporting financial data. This data is frequently used by internal and external stakeholders for decision-making and performing actions. Consequently, the financial information reliability influences the relationship between the organization and its stakeholders. It is recongnized as a fundamental criterion for efficient decision-making and effective actions. However, the financial information is a component of a system, namely financial communication. This system encompasses a set of processes using first quantitative data to support communication strategy at corporate level. In this sense, organization leverages by financial communication its corporate disclosure about value creation processes. This disclosure is communicated passing through different tools, among others, the website. So, this system is virtual enabling instantaneous transfer of financial information. Through internet organization communicates its financial performance and corporate development allowing stakeholders the ability to assess risks and explore opportunities of businesses.

Theoretically, virtual financial communication, used to outline how organization is communicating throughout internet more effectively and efficiently with stakeholders, seems to be not deliberately studied. Indeed, the 
literature review deals with the financial communication content. Nevertheless, it does not consider whether this financial communication is done throughout internet technology. There is no prove regarding on the relationship between virtual financial communication and financial performance. This research tries to provide more insights about virtual financial communication content made by organizations quoted in stock exchange, and thus the possible association with financial performance communicated by financial information system. The purpose of this research paper is to investigate about the potential predictability of virtual financial communication content throughout specific performance indicators.

Our theoretical background is based on the existing literature concerning the main points of the research. First, the researches outlining financial communication recognized as a policy for revealling organization's disclosure to stakeholders. Second, the corporate finance literature is also used to explain the importance of financial information and how it could be treated and communicated. Third, virtual financial communication is a new concept used to emphasize organization policy using internet for communicating and interacting in order to serve a specific corporate agenda.

\section{Literature Review}

In organization management, communication is a critical function for transfering information to different stakeholders. This transfert of information has different purposes and objectives. That having been said, information communication activities stresse the depth belief in the management mindset that the corporate development depends on how organization is communicating and interacting with the stakeholders. This belief is more strengthened and became well integrated in management practices due to the globalization, corporate crises and financial crises (Cornelissen, 2017). In that perspective, organization has to perform a corporate communication. Financial Times lexicon defines this communication as a function serving as the conscience of the corporation and is responsible for the organisation's reputation. Previously called "public relations" or "public affairs," corporate communication has taken on new importance in the 21st century. Therefore, the corporate communication oversees different kind of activities such as: media relations, internal communications, reputation management, corporate responsibility, financial communication, government affairs, marketing communication, etc. As a significant part of corporate communication, financial communication aims to provide organization the ability to deal with the complex communication challenges regarding financial transactions and markets.

\subsection{Financial Information}

Financial information is crucial for different organization's stakeholders (investors, shareholders, clients, regulators, etc.). This kind of information is found in financial statements and financial reports. These documents contain all of the financial information about organization businesses, performance, transactions in stock exchange, equity price, etc. For many reasons, financial information should be displayed propely to make an insightful content (Firth, 1981; Aaker \& Jacobson, 1994; Guay \& Harford, 2000; Asquith, Mikhail \& Au, 2005; DeFond, Hung \& Trezevant, 2007). Subsequently, the content is supposed to be useful for many stakeholders (Titman \& Trueman, 1986; Shaikh, 1999; Hodge, 2003; Sarapaivanich \& Kotey, 2006) by providing them the transparency (Bushman \& Smith, 2003), the information needed (Caba Pérez, Hernández \& Bolívar, 2005; Wittenberg-Moerman, 2008), the ability for an effective decision-making (Chewning \& Harrell, 1990; Lyon, Lumpkin \& Dess, 2000). All these financial information characteristics are thaught as a way of judging the quality of the information communicated towards stakeholders (Cappiello, Francalanci \& Pernici, 2003; Beuselinck \& Manigart, 2007; Vanden, 2008; Van Caneghem \& Van Campenhout, 2012). The financial information quality influences how organization is making his disclosure for serving the corporate agenda as well as reducing the problem of information asymmetry of the stakeholders (Penno, 1997; LU, 2014; Peihani, 2017).

The management has to set up a well-machted system to make the financial information accurate and accessible. Thus, the system should be well designed (Lockman \& Minsky, 1984; Stocken \& Verrecchia, 2004; Tsamenyi, Cullen \& González, 2006; French, Baily, Campbell, Cochrane, Diamond, Duffie, ... Stulz, 2010) for generating financial information to support effective decision-making (Gordon \& Miller D, 1976; Lumpkin et al., 2000; Peihani, 2017). The American accounting association emphasizes that system is vital., given the essentially total reliance of accounting and auditing on computerized information systems. This system within structure was among the first users of business computing. It does not operate in isolation because information technology plays a ubiquitous role in all aspects of the lives of organization and its stakeholders. In other words, it is recognized that financial information system consists of primary components such as: people, data, procedures, process interdpendancy, information technology infrastructure, internal control, etc. These components highlight 
the environment in which financial information is captured, stored, processed and reported (Krishnan, Peters, Padman \& Kaplan, 2005; Brazel \& Agoglia, 2007; Christensen, 2010; Bai, Nunez, \& Kalagnanam, 2012).

Financial information system is established to provide an appropriate framework for dealing effectively with all the aspects related to financial information (Krishnan et al., 2005; Brazel et al., 2007). These aspects expose how this system should operate (Stocken et al., 2004; Doan \& McKie, 2017) and the changes affecting its environment (ERP system application, audit-related risks, etc.). In other words, the way how organization behaves in financial information environment is called the financial communication (Brazel et al., 2007; Rensburg \& Botha, 2014; Bargenda, 2015).

\subsection{Financial Communication}

In practice, organization is dealing with financial information throughtout a wide range of processes and tools (Jones \& Roberts, 2006; Brazel et al., 2007; Lippman, 2009; Wang, 2013; Janvrin \& Mascha, 2014; Habib, Ranasinghe \& Huang, 2018; Weetman, 2018). By using financial information, financial communication is viewed as a communication strategy endeavoring primarily to manage the investor relations. With this strategy, organization intends to interface with current and potential financial stakeholders such as retail investors, institutional investors, and financial analysts. The effectiveness of this strategy depends on the organization's capabilities for creating a pool of latent demand for the company's shares; reducing churn in the company's shares and keep price volatility low; giving an accurate representation of the company's past performance; providing credible predictions of the company's future performance; maximizing the company's market value, minimizing its financing costs, and reducing its cost of credit and cost of capital (Riel \& Fombrun, 2007; Huang, 2018).

Financial communication should be understood as being part of what has commonly been called the corporate communication. Is recognized as an intangible asset of primary importance for corporate development (Salvioni, 2002). Additionally, it is becoming more and more interesting and more relevant for any organization whose equities or bonds are publicly traded on a stock exchange (Riel \& Fombrun, 2007).

Basically, financial communication deals with accounting data to be in conformity with all regulatory requirements (Ho, Liu \& Ramanan, 1997; Liang \& Xiaoyan, 2007; Chen, Hemmer, \& Zhang, 2007; Bai, Nunez, \& Kalagnanam, 2012). In general., financial communication provides more insights about financial performance which is traditionally associated with organization's communication agenda (Johnston, Reed, Lawrence \& Onken, 2007; Choi \& Wang, 2009; Gentry \& Shen, 2010). Nonetheless, it is also shaped in a way which enables organization to make good corporate governance (Salvioni, 2002; Bushman et al., 2003; Picou \& Rubach, 2006; Salama \& Putnam, 2013; Bhagat \& Bolton, 2013) and deliver promises towards specific stakeholders (Miles, Munilla \& Darroch, 2006; Harrison, Bosse \& Phillips, 2010).

Theoretically, financial communication impacts the organization disclosure. In fact, the financial communication content emphasizes the design of the organization disclosure guidance (Gigler \& Hemmer, 2001; Bushman et al., 2003; Beretta \& Bozzolan, 2004; Stocken \& Verrecchia, 2004; Jiao, 2011). This design emphasizes the organization's abilities to make a suitable disclosure of information about value-creation processes and business strategies (Frost, Gordon \& Hayes, 2006; Bagnoli \& Watts, 2007; Malenko, 2014). In that perspective, organization could make a voluntary disclosure by providing information beyond requirements forced by financial markets regulators (Beretta et al., 2004; Boesso \& Kumar, 2007). Therefore, organization seeks to influence stakeholders in their decision-making throughtout revealing its business model, announcing future earnings and making promises (Miller, 2002; Graham, Harvey \& Rajgopal., 2005; Frost et al., 2006; Jiao, 2011).

By doing so, organisation uses information technology like internet for being more effective in its disclosure (Marston, 2003). Based on website, internet disclosure provides a new perspective for organization to design and shapes its financial communication agenda (Andrikopoulos, Merika, Triantafyllou \& Merikas, 2013).

\subsection{Virtual Financial Communication}

Information technology like internet affects organizational design, intelligence, and decision making (Huber, 2000). In fact, organization uses its website for different purposes, among others, managing the investor relations. In this sense, it becomes clear that internet has dramatically increased the ability of compny's officers to convey information quickly and reliably to the financial markets, and thereby increasing their perceived transparency and responsiveness (Riel et al., 2007). Consequently, organizations listed in financial markets use more and more internet to present financial information (Marston, 2003; Pirchegger \& Wagenhofer, 2010; Gowthorpe \& Amat, 2010). Throughtout its website, organization is being able to make financial information more easily accessed by a larger group of stakeholders, regardless their level of financial sophistication (Ettredge, Richardson \& Scholz, 
2001; Lunardi, João Becker, Maçada \& Dolci, 2014).

Using internet, financial communication is virtual. Accordingly, the actual and potential development of the internet as a means of conducting the corporate disclosure (Gowthorpe et al., 2010; Nurunnabi \& Alam Hossain, 2012; Guillamón-Saorín \& Martínez-López, 2013; Lunardi et al., 2014) impacts the organizational behavior towards specific stakeholders (investors and regulators). This behavior is more evident throughtout the nature of on-line content addressed to stakeholders. This content could be basic when it is established to fit financial markets regulators rules (Chen et al., 2007; Bai et al., 2012). However, it is mainly oriented stakeholders in the case of making more and more financial information available via the website. The level of this availability is beyond which is required by financial market authorities (Miller, 2002; Graham et al., 2005; Frost et al., 2006; Boesso et al., 2007). This internet disclosure affects partially financial performance, and also, it is viewed as a requirement for it (Andrikopoulos et al., 2013).

In theory, there is a lack of studies treating the predictability of virtual financial communication content via financial performance. In fact, many researches investigate to what extend financial communication could be associated with financial performance (Miller, 2002; Frost et al., 2006; Jiao, 2011; Andrikopoulos et al., 2013). Nonetheless, the financial performance predictability of virtual financial communication content seems to be not adequately studied.

In this research, we aim to study the option to predict virtual financial communication content throughthout financial indicators. Therefore, we attempt to study whether financial indicators could predict the nature of virtual financial communication content. We choose PER - Price Earning Ratio and PBR - Price to Book Ratio as the most financial indicators used to measure organization market performance and value. As well, we use OP - Operating Profit as the better indicator measuring the organization's earning power. The choice of financial indicators as predictors is justified by the fact that they are frequently theoretically associated with financial communication (Miller, 2002; Frost et al., 2006; Jiao, 2011; Andrikopoulos et al., 2013). Hence, we investigate how independent variables - the financial indicators discriminate among the members of groups constructed based on virtual financial communication content.

Three hypotheses were set up:

$\boldsymbol{H}_{1}$ : PER is a good predictor of virtual financial communication content.

$\boldsymbol{H}_{2}: P B R$ is a good predictor of virtual financial communication content.

$\boldsymbol{H}_{3}:$ OP is a good predictor of virtual financial communication content.

\section{Method}

For testing the hypotheses cited above, quantitative research approach is used in this study, because it is well-matched to the subject of our research.

\subsection{Participant (Subject) Characteristics}

In this paper, we seek to study the possibility for predicting virtual financial communication content throughout specific financial indicators. Our research is conducted with companies listed in Casablanca stock exchange in Morocco. This choice is justified by the fact that these companies plublished regulary their financial statements and reports in their websites. As well, these companies are operating in different industries and represent all sizes companies categories. So, we cover for the most part the Moroccan business landscape.

\subsection{Sampling Procedures}

To fit the purpose of this research, convenience sampling method was applied for getting data (financial statements, annual reports, newsletters, etc.) from companies' websites. 64 companies quoted in Casablanca stock exchange were involved in the study.

\subsection{Measures and Covariates}

For this research, the data-collection process was based on data found in companies's websites. We use a content analysis of websites for each company in ordre to lay out the nature of its virtual financial communication content. So, two groups of companies are constructed. Based on the financial information, we use three financial indicators for these two groups. The reasons of this choice were efficiency in data gathering to fit the requirements of discriminant analysis.

Two categories of variables were used in this survey. First, virtual financial communication content is a qualitative variable. It contains two categories such as: basic and content-oriented stakeholders. It was measured throught companies websites'content analysis driven by multiple-choice survey questions with exhaustive and 
mutually exclusive items. While doing so, we try to highlight the nature of the virtual financial communication content. Second, three quantitative variables such as: PER - Price Earning Ratio, PBR - Price Book Ratio and OP - Operating Profit representing financial performance indicators guatered from Casablanca stock exchange website. These indicators refer to 2016 financial data.

\section{Results and Data Analysis}

This section illustrates the results of discriminant analysis conducted throughtout SPSS. The data used in this analysis are from Casablanca stock exchange data file. SPSS output is displayed in tables.

We try to study the relationship between one categorical variable and three continuous variables. In particular, the aim is to know the dimensions needed to express this relationship. Therefore, we are interested to predict a classification based on the continuous variables in order to assess to what extend the continuous variables differentiate the categories constructed. As well, we are interested to investigate the degree to which the continuous variables can be used to discriminate between the groups.

Table 1 recapitulates the analysis dataset in terms of valid and excluded observations. In our study, all of the observations in the dataset are valid.

Tab 1. Analysis case processing summary

\begin{tabular}{llll}
\hline Unweighted Cases & $\mathbf{N}$ & Percent \\
\hline Valid & & 64 & 100,0 \\
Excluded & Missing or out-of-range group codes & 0 &, 0 \\
& At least one missing discriminating variable & 0 &, 0 \\
& $\begin{array}{l}\text { Both missing or out-of-range group codes and at least } \\
\text { one missing discriminating variable }\end{array}$ & 0 &, 0 \\
Total & & $\mathbf{6 4}$ & $\mathbf{1 0 0 , 0}$ \\
\hline
\end{tabular}

The second table displays the distribution of observations into two groups within virtual financial communication content. Thus, we can see the frequency of observations into each of the two groups. In this case, we can see that the PER mean values are approximatively the same between the two groups. However, we haven't the same situation regarding the OP values. In addition, we observe that the weighted number of observations in each group is equal to the unweighted number of observations in each group.

Tab 2. Group statistics

\begin{tabular}{|c|c|c|c|c|c|}
\hline \multirow[t]{2}{*}{ Fin_Com_Content } & & \multirow[t]{2}{*}{ Mean } & \multirow[t]{2}{*}{ Std. Deviation } & \multicolumn{2}{|c|}{ Valid N (listwise) } \\
\hline & & & & Unweighted & Weighted \\
\hline \multirow[t]{3}{*}{ Basic } & PER & 28,5854 & 67,22313 & 41 & 41,000 \\
\hline & PBR & 2,4146 & 2,20199 & 41 & 41,000 \\
\hline & $\mathbf{O P}$ & 265604769,0956 & 456332716,19241 & 41 & 41,000 \\
\hline \multirow[t]{3}{*}{ Content-oriented stakeholders } & PER & 17,9130 & 6,74141 & 23 & 23,000 \\
\hline & PBR & 2,3913 & 1,77711 & 23 & 23,000 \\
\hline & $\mathbf{O P}$ & 1699166638,8383 & 2744710627,99358 & 23 & 23,000 \\
\hline \multirow[t]{3}{*}{ Total } & PER & 24,7500 & 53,96001 & 64 & 64,000 \\
\hline & PBR & 2,4063 & 2,04488 & 64 & 64,000 \\
\hline & OP & 780791066,0344 & 1800995280,75178 & 64 & 64,000 \\
\hline
\end{tabular}

In the table 3, the first column indicates the canonical linear discriminant function. In this analysis, virtual financial communication content has two levels and three discriminating variables were used, so one function is calculated. This function is a projection of the data onto a dimension that best differentiates between the groups. In the second column, we have the eigenvalue of the matrix product of the inverse of the within-group sums-of-squares and cross-product matrix and the between-groups sums-of-squares and cross-product matrix. In our analysis, the eigenvalue is 0.191 . The importance of this eigenvalue stresses the function's discriminating abilities. As well, the $\%$ of variance indicates that the function calculated accounts for $100 \%$ of the discriminating ability of the discriminating variables. The final column is about the canonical correlation of the predictor variables (PER, PBR and OP) and the two groups in virtual financial communication content (basic and 
content-oriented stakeholders). From this analysis, the canonical correlation value is 0.400 .

Table 3. Eigenvalues

\begin{tabular}{lllll}
\hline Function & Eigenvalue & \% of Variance & Cumulative \% & $\begin{array}{l}\text { Canonical } \\
\text { Correlation }\end{array}$ \\
\hline 1 &, $191^{\mathrm{a}}$ & 100,0 & 100,0 &, 400 \\
\hline
\end{tabular}

${ }^{a}$ First 1 canonical discriminant functions were used in the analysis.

The Wilks' Lambda value displayed by the table 4 is 0.840 . Besides, the Chi-square (10.566) testing that the canonical correlation of the function calculated is equal to zero. As a result, we have the null hypothesis is that the function has no discriminating ability. This hypothesis is tested using this Chi-square statistic. The $p$-value associated with the Chi-square value is 0.014 (smaller than 0.05 ). So, the null hypothesis is rejected. It indicates that there is a significant difference between the two groups based on the predictor variables.

Tab 4. Wilk's lambda

\begin{tabular}{lllll}
\hline Test of Function(s) & Wilks' Lambda & Chi-square & df & Sig. \\
\hline 1 &, 840 & 10,566 & 3 &, 014 \\
\hline
\end{tabular}

The table 5 shows the coefficients that can be used to estimate the discriminant score.

Tab 5. Standardized canonical discriminant function coefficients

\begin{tabular}{ll}
\hline & Function 1 \\
\hline PER &,- 234 \\
PBR &,- 212 \\
OP &, 991 \\
\hline
\end{tabular}

The magnitudes of these coefficients indicate how strongly the discriminating variables affect the score. In our analysis, we observe that the coefficient for OP (0.991) in the function is greater in magnitude than the coefficients for the other two variables (PER and PBR smaller than 0.30). In consequence, OP will have the greatest impact ( $\boldsymbol{H}_{3}$ is accepted) of the three $\left(\boldsymbol{H}_{1}\right.$ and $\boldsymbol{H}_{2}$ are rejected) on the discriminant score (appendix A).

The table 5 indicates the canonical structure of the discriminant function. It represents the correlations between the three continuous discriminating variables (PER, PBR and OP) and the dimensions created with the discriminant function. In the analysis, this correlation is strong in the case of OP (0.955).

Tab 5. Structure matrix

\begin{tabular}{ll}
\hline & Function 1 \\
\hline OP &, 955 \\
PER &,- 220 \\
PBR &,- 013 \\
\hline
\end{tabular}

In the table 6, we find the means of the discriminant function scores by group for the function calculated above. Therefore, we can see that the basic group has a mean of -0.322 , the content-oriented stakeholders group has a mean of 0.574 . 
Tab 6. Functions at group centroids

\begin{tabular}{ll}
\hline Fin_Com_Content & Function \\
& 1 \\
\hline Basic &,- 322 \\
Content-oriented stakeholders &, 574 \\
\hline
\end{tabular}

Table 7 is similar to the Analysis Case Processing Summary displayed by table 1. However, in this table we find "Processed" cases that were successfully classified based on the discriminant analysis. Also, we are listed the reasons why an observation may not have been processed. In the analysis, we can see that all of the observations in the dataset were successfully classified.

Tab 7. Classification processing summary

\begin{tabular}{lll}
\hline Processed & & 64 \\
\hline Excluded & Missing or out-of-range group codes & 0 \\
& At least one missing discriminating variable & 0 \\
Used in Output & & 64 \\
\hline
\end{tabular}

The table 8 shows the distribution of observations into the virtual financial communication content groups used as a starting point in the analysis. The default prior distribution is an equal allocation into the two groups. The discriminant function has classified 41 as basis and 23 as content-oriented stakeholders. So, this function calculated is able to classify all of the observations (appendix B).

Tab 8. Prior Probabilities for Groups

\begin{tabular}{llll}
\hline Fin_Com_Content & Prior & \multicolumn{2}{c}{ Cases Used in Analysis } \\
& & Unweighted & Weighted \\
\hline Basic &, 500 & 41 & 41,000 \\
Content-oriented stakeholders &, 500 & 23 & 23,000 \\
Total & 1,000 & 64 & 64,000 \\
\hline
\end{tabular}

\section{Discussion}

The aim of this paper is to highlight, throughout discriminant analysis, the possibility for discriminating among the two groups constructed based on virtual financial communication content. In such a case, three financial indicators are applied as predictor variables. Our findings involve the enlightenment of some insights raised by observing the results derived from the analysis. First, OP - Operating Profit is underlined as an indicator that has the strong discriminating ability between the two groups constructed. For that reason, the content of virtual financial communication is principally determined by the OP. In other words, this indicator could be used to predict the content of virtual financial communication content whether is basic or oriented stakeholder. So, the trend of OP puts emphasis on to what extend the content of the virtual financial communication is oriented stakeholders. Second, the indicators such as PER - Price Earning Ratio and PBR - Price to Book Ratio are stressed as indicators without significant discriminating ability among the two groups constructed. Therefore, these indicators could not be used for predicting the tendency of virtual financial communication content. Subsequently, to what extend the virtual financial communication content is oriented stakeholders could be determined not considering the values of these two indicators. These three indicators represent the organization performance and market value from different points of view. The OP is one of the indicators preferred by investors because it presents the organization's financial situation more positively than others indicators like the Net Profit (NP). In addition, this indicator allow for a significant comparison within industries for the reason that it is related to organization core business. Financial indicators like PER and PBR are more related to organization market performance and value rather then the performance related to organization core operations. The PER is a financial indicator used as a method for determining whether organization performance in financial market is evaluated in line with the performance measured by the accounting funtion. This financial indicator gives emphasis to the stakeholders' perception of the risk and future earnings. This perception depends on the stakeholders' access to information or their interpretation of the organization disclosure. About the PBR, it is an 
indicator that gives some insights of whether stakeholders are evaluating above for what should be done regarding organization's book value. This value surplus calls attention to how stakeholders are interpreting and dealing with the content of organization financial disclosure.

Some convergence between our findings and the literature is found. Indeed, as displayed above financial market indicators like PER and PBR don't give adequate emphasis to the nature of virtual financial communication content. Subsequently, these indicators aren't insightful about the ability to predict whether organization disclosure is basic or oriented stakeholders. Expressly, organization quoted in financial markets could conduct the same financial communication strategy in despite of their market performance and value. In theory, there is a lack of consensus about the relationship between the performance and the strength of financial communication. Some researches outline the fact that performing organization is by and large using a great financial communication strategy. Conversely, others theoretical frameworks argues that performing organization disclosure less to protect themselves from specific stakeholders (Talmor, 1981; Hennessy, Livdan \& Miranda, 2010; Connelly, Certo, Ireland \& Reutzel, 2011; Esqueda, 2016). The OP is considered to be more significant about predicting financial communication content because it is related to organization's success and efficiency. It is linked to organization's ability to make profit and provide more and more insights about its financial health and opportunities for growth. This indicator brings to light the real organization's core operations performance. Its value is not manipulated, like PER and PBR, for serving specific disclosure towards stakeholders (Gentry \& Shen, 2010). In that perspective, virtual financial communication is focusing on ensuring the availability of accounting indicators (i.e. OP) on the Web because it has the potential to considerably increase the stakeholders' interest (Ho, Liu, \& Ramanan, 1997, Chen, Hemmer \& Zhang, 2007; Gaa, 2009; Pirchegger et al., 2010; Gowthorpe et al., 2010; Nurunnabi et al., 2012; Guillamón-Saorín et al., 2013). As a result, the virtual financial communication content would be more oriented stakheholders because it will be based on the assumptions of usefulness, clarity and technicality (Ettredge et al., 2001). These assumptions highlight the trend of some accounting indicators by which stakeholders assess organization's performance and value. These indicators, at particular level, push organization to shape its virtual financial communication content for being more oriented stakeholders (Miller, 2002; Graham et al., 2005; Frost et al., 2006). This content deals with the presentation of the accounting based information (financial statements, annual reports, etc), but others financial and non-financial information would be also included in corporate website for making organization disclosure more oriented stakeholders (Boesso et al., 2007; Andrikopoulos et al., 2013).

Finally, it could be argued that the virtual financial communication content could be predicted throughtout performance indicator. At this point, it may question at what level of specific performance indicators the virtual financial communication content is more (or less) oriented stakeholders. Furthermore, corporate website used by organization to make public diverse information (financial and non-financial) is shaped for serving specific disclosure agenda. That agenda lies emphasis on the nature of the virtual financial communication content, and thus whether is it oriented stakeholders or basic.

\section{Conclusion}

This article had as purpose to improve our knowledge about the ability of specific performance indicators for predicting the nature of the virtual financial communication content. For this purpose, we try to highlight whether the corporate disclosure is oriented stakeholders when we look at these indicators. Therefore, we use heterogeneous performance indicators published by organizations quoted in Moroccan stock exchange in order to explore their corporate websites content.

This research has some limitations by which further research questions could be opened. These limits can be summarized in four points. First, results obtained from this study are related to Moroccan context. Accordingly, future studies could be conducted in other North African stock exchanges in order to deepen our findings. Second, in this research we use three performance indicators but others indicators are also available, and thus could be added to investigate the strength of their predictability regarding the virtual financial communication content. Third, we used only two items to explain the nature of the virtual financial communication content. However, further researches can use more than two to discuss and stress all of the coporate disclosure categories. Fourth, we used the discriminant analysis to study to what extend the indicators mentioned above are able for discriminating between organizations about their financial communication content, but others analysis like MANOVA and Logistic Regression are interesting to investigate deeplty the relationship between the financial performance indicators and the corporate disclosure when using technology like internet.

\section{References}

Aaker, D., \& Jacobson, R. (1994). The Financial Information Content of Perceived Quality. Journal of 
Marketing Research, 31(2), 191-201. https://doi.org/10.2307/3152193

Andrikopoulos, A., Merika, A. A., Triantafyllou, A., \& Merikas, A. G. (2013). Internet disclosure and corporate performance: A case study of the international shipping industry. Transportation Research Part A: Policy and Practice, 47, 141-152. https://doi.org/10.1016/j.tra.2012.10.016

Asquith, P., Michael, B. M., \& Andrea, S. A. (2005). Information content of equity analyst reports. Journal of Financial Economics, 75(2), 245-282. https://doi.org/10.1016/j.jfineco.2004.01.002

Bagnoli, M., \& Watts, S. (2007). Financial Reporting and Supplemental Voluntary Disclosures. Journal of Accounting Research, 45(5), 885-913. Retrieved from http://www.jstor.org/stable/4622060

Bai, X., Nunez, M., \& Kalagnanam, J. (2012). Managing Data Quality Risk in Accounting Information Systems. Information Systems Research, 23(2), 453-473. Retrieved from http://www.jstor.org/stable/23274433

Bai, X., Nunez, M., \& Kalagnanam, J. (2012). Managing Data Quality Risk in Accounting Information Systems. Information Systems Research, 23(2), 453-473. Retrieved from http://www.jstor.org/stable/23274433

Barbara, P., \& Alfred, W. (2010). Financial information on the Internet: A survey of the homepages of Austrian companies, European Accounting Review, 8(2), 383-395. https://doi.org/10.1080/096381899336113

Bargenda, A. (2015). Sense-making in financial communication: Semiotic vectors and iconographic strategies in banking advertising. Studies in Communication Sciences, 15(1), 93-102, https://doi.org/10.1016/j.scoms.2015.01.001

Beretta, S., \& Bozzolan, S. (2004). A framework for the analysis of firm risk communication. The International Journal of Accounting, 39(3), 265-288. https://doi.org/10.1016/j.intacc.2004.06.006

Beuselinck, C., \& Manigart, S. (2007). Financial Reporting Quality in Private Equity Backed Companies: The Impact of Ownership Concentration. Small Business Economics, 29(3), 261-274. Retrieved from http://www.jstor.org/stable/40229556

Bhagat, S., \& Bolton, B. (2013). Director Ownership, Governance, and Performance. The Journal of Financial and Quantitative Analysis, 48(1), 105-135. Retrieved from http://www.jstor.org/stable/43303794

Brazel, J. F., \& Agoglia, C. P. (2007), An Examination of Auditor Planning Judgements in a Complex Accounting Information System Environment. Contemporary Accounting Research, 24, 1059-1083. https://doi.org/10.1506/car.24.4.1

Bushman, R. M., \& Smith, A. J. (2003). Transparency, Financial Accounting Information, and Corporate Governance. Economic Policy Review, 9(1). Retrieved from https://ssrn.com/abstract=795547

Caba Pérez, C. M., López Hernández, A., \& Rodríguez Bolívar, M. P. (2005). Citizens' access to on-line governmental financial information: Practices in the European Union countries. Government Information Quarterly, 22(2), 258-276. https://doi.org/10.1016/j.giq.2005.02.002

Cappiello, C., Francalanci, C., \& Pernici, B. (2003). Time-Related Factors of Data Quality in Multichannel Information Systems. Journal of Management Information Systems, 20(3), 71-91. Retrieved from http://www.jstor.org/stable/40398641

Catherine, G., \& Oriol, A. (2010). External reporting of accounting and financial information via the Internet in Spain, European Accounting Review, 8(2), 365-371. https://doi.org/10.1080/096381899336096

Chen, Q., Hemmer, T., \& Zhang, Y. (2007). On the Relation between Conservatism in Accounting Standards and Incentives for Earnings Management. Journal of Accounting Research, 45(3), 541-565. Retrieved from http://www.jstor.org/stable/4622044

Chewning, E. G., \& Harrell, A. M. (1990). The effect of information load on decision makers' cue utilization levels and decision quality in a financial distress decision task. Accounting, Organizations and Society, 15(6), 527-542. https://doi.org/10.1016/0361-3682(90)90033-Q

Choi, J., \& Wang, H. (2009). Stakeholder Relations and the Persistence of Corporate Financial Performance. Strategic Management Journal, 30(8), 895-907. Retrieved from http://www.jstor.org/stable/20536084

Christensen, J. (2010). Accounting Errors and Errors of Accounting. The Accounting Review, 85(6), 1827-1838. Retrieved from http://www.jstor.org/stable/27895903

Claire, M. (2003). Financial reporting on the Internet by leading Japanese companies. Corporate Communications: An International Journal, 8(1), 23-34. https://doi.org/10.1108/13563280310458894 
Connelly, B., Certo, T., Ireland, R., \& Reutzel, R. C. (2011). Signaling Theory: A Review and Assessment. Journal of Management, 37, 39-67. https://doi.org/10.1177/0149206310388419

Cornelissen, J. (2017). Corporate Communication: A Guide to Theory and Practice. Rotterdam, Netherlands: Sage publishing.

DeFond, M., Hung, M., \& Trezevant, R. (2007). Investor protection and the information content of annual earnings announcements: International evidence. Journal of Accounting and Economics, 43(1), 37-67. https://doi.org/10.1016/j.jacceco.2006.09.001.

Doan, M. A., \& McKie, D. (2017). Financial investigations: Auditing research accounts of communication in business, investor relations, and public relations (1994-2016). Public Relations Review, 43(2), 306-313. https://doi.org/10.1016/j.pubrev.2017.02.010.

Encarna, G. S., Francisco, J. M. L. (2013). Corporate financial communication and the internet: manipulating investor audiences? Online Information Review, 37(4), 518-537. https://doi.org/10.1108/OIR-10-2011-0142

Esqueda, O. A. (2016). Signaling, corporate governance, and the equilibrium dividend policy. The Quarterly Review of Economics and Finance, 59, 186-199. https://doi.org/10.1016/j.qref.2015.06.005

Ettredge, M., Richardson, V., \& Scholz, S. (2001). The Presentation of Financial Information at Corporate Web Sites. International Journal of Accounting Information Systems, 2, 149-168. https://doi.org/10.1016/S1467-0895(00)00017-8

Firth, M. (1981). The Relative Information Content of the Release of Financial Results Data by Firms. Journal of Accounting Research, 19(2), 521-529. https://doi.org/10.2307/2490878

Frank, B. G., \& Thomas, H. (2001). Conservatism, Optimal Disclosure Policy, and the Timeliness of Financial Reports. The Accounting Review, 76(4), 471-493. https://doi.org/10.2308/accr.2001.76.4.471

French, K., Baily, M., Campbell, J., Cochrane, J., Diamond, D., Duffie, D., ... Stulz, R. (2010). The Squam Lake Report: Fixing the Financial System. Oxford: Princeton University Press. Retrieved from http://www.jstor.org/stable/j.ctt7sjcm

Frost, C., Gordon, E., \& Hayes, A. (2006). Stock Exchange Disclosure and Market Development: An Analysis of 50 International Exchanges. Journal of Accounting Research, 44(3), 437-483. Retrieved from http://www.jstor.org/stable/3542331

Gaa, J. (2009). Corporate Governance and the Responsibility of the Board of Directors for Strategic Financial Reporting. Journal of Business Ethics, 90, 179-197. Retrieved from http://www.jstor.org/stable/40665293

Gentry, R., \& Shen, W. (2010). The Relationship between Accounting and Market Measures of Firm Financial Performance: How Strong Is It? Journal of Managerial Issues, 22(4), 514-530. Retrieved from http://www.jstor.org/stable/25822528

George, P. H. (2000). Chapter 9 - A Theory of the Effects of Advanced Information Technologies on Organizational Design, Intelligence, and Decision Making. In David E. Smith (Ed.), Knowledge, Groupware and the Internet (pp. 221-254). Boston: Butterworth-Heinemann. https://doi.org/10.1016/B978-0-7506-7111-8.50011-1

Giacomo, B., \& Kamalesh, K. (2007). Drivers of corporate voluntary disclosure: A framework and empirical evidence from Italy and the United States. Accounting, Auditing \& Accountability Journal, 20(2), 269-296. https://doi.org/10.1108/09513570710741028

Gordon, L. A., \& Miller, D. (1976). A contingency framework for the design of accounting information systems. In Emmanuel C., Otley D., Merchant K. (Eds.), Readings in Accounting for Management Control. Springer, Boston, MA. https://doi.org/10.1007/978-1-4899-7138-8_26

Graham, J. R., Harvey, C. R., \& Rajgopal, S. (2005). The economic implications of corporate financial reporting. Journal of Accounting and Economics, 40(1-3), 3-73. https://doi.org/10.1016/j.jacceco.2005.01.002

Guay, W., \& Harford, J. (2000). The cash-flow permanence and information content of dividend increases versus $\begin{array}{lllll}\text { repurchases. Journal of Financial } & \text { Economics, } & \text { 57(3), } & \text { 385-415. }\end{array}$ https://doi.org/10.1016/S0304-405X(00)00062-3

Habib, A., Ranasinghe, D., \& Huang, H. J. (2018). A literature survey of financial reporting in private firms. Research in Accounting Regulation. https://doi.org/10.1016/j.racreg.2018.03.005

Harrison, J., Bosse, D., \& Phillips, R. (2010). Managing for Stakeholders, Stakeholder Utility Functions, and 
Competitive Advantage. Strategic Management Journal, 31(1), 58-74. Retrieved from http://www.jstor.org/stable/27735509

Hennessy, C., Livdan, D., \& Miranda, B. (2010). Repeated Signaling and Firm Dynamics. The Review of Financial Studies, 23(5), 1981-2023. Retrieved from http://www.jstor.org/stable/40604836

Ho, L., Liu, C., \& Ramanan, R. (1997). Open-Market Stock Repurchase Announcements and Revaluation of Prior Accounting Information. The Accounting Review, 72(3), 475-487. Retrieved from http://www.jstor.org/stable/248481

Hodge, F. (2003). Investors' Perception of Earnings Quality, Auditor Independence, and the Usefulness of Audited Financial Information. Accounting Horizons (Supplement), 37-48. https://doi.org/10.2308/acch.2003.17.s-1.37

Janvrin, D., \& Mascha, M. F. (2014). The financial close process: Implications for future research. International Journal of Accounting Information Systems, 15(4), 381-399. https://doi.org/10.1016/j.accinf.2014.05.007

Jiao, Y. (2011). Corporate Disclosure, Market Valuation, and Firm Performance. Financial Management, 40(3), 647-676. Retrieved from http://www.jstor.org/stable/41237920

Johnston, M., Reed, K., Lawrence, K., \& Onken, M. (2007). The Link between Communication and Financial Performance in Simulated Organizational Teams. Journal of Managerial Issues, 19(4), 536-553. Retrieved from http://www.jstor.org/stable/40604586

Jones, C., \& Andrea, A. R. (2006). Management of Financial Information in Charitable Organizations: The Case of Joint-Cost Allocations. The Accounting Review, 81(1), 159-178. Retrieved from http://www.jstor.org/stable/4093132

Krishnan, R., Peters, J., Padman, R., \& Kaplan, D. (2005). On Data Reliability Assessment in Accounting Information Systems. Information Systems Research, 16(3), 307-326. Retrieved from http://www.jstor.org/stable/23015757

Liang, P., \& Wen, X. Y. (2007). Accounting Measurement Basis, Market Mispricing, and Firm Investment Efficiency. Journal of Accounting Research, 45(1), 155-197. Retrieved from http://www.jstor.org/stable/4622025

Lippman, E. (2009). Accountants' Responsibility for the Information They Report: An Historical Case Study of Financial Information. The Accounting Historians Journal, 36(1), 61-79. Retrieved from http://www.jstor.org/stable/40698400

Lockman, A., \& Minsky, N. (1984). Designing Financial Information Systems for Auditability. Journal of Management Information Systems, 1(1), 50-62. Retrieved from http://www.jstor.org/stable/40384525

Lu, H. (2014). Does Disclosure of Non-Financial Statement Information Reduce Firms' Propensity to Under-Invest? Quarterly Journal of Finance and Accounting, 51(3-4), 1-44. Retrieved from http://www.jstor.org/stable/qjfinacct.51.3-4.1

Lunardi, G. L., Becker, J. L., Gastaud Maçada, A. C., \& Dolci, P. C. (2014). The impact of adopting IT governance on financial performance: An empirical analysis among Brazilian firms. International Journal of Accounting Information Systems, 15(1), 66-81. https://doi.org/10.1016/j.accinf.2013.02.001

Lyon, D. W., Lumpkin, G. T., \& Dess, G. G. (2000). Enhancing entrepreneurial orientation research: operationalizing and measuring a key strategic decision making process. Journal of Management, 26(5), 1055-1085. https://doi.org/10.1016/S0149-2063(00)00068-4.

Malenko, N. (2014). Communication and Decision-Making in Corporate Boards. The Review of Financial Studies, 27(5), 1486-1532. Retrieved from http://www.jstor.org/stable/24465407

Miles, M., Munilla, L., \& Darroch, J. (2006). The Role of Strategic Conversations with Stakeholders in the Formation of Corporate Social Responsibility Strategy. Journal of Business Ethics, 69(2), 195-205. Retrieved from http://www.jstor.org/stable/25123947

Miller, G. (2002). Earnings Performance and Discretionary Disclosure. Journal of Accounting Research, 40(1), 173-204. Retrieved from http://www.jstor.org/stable/3542434

Mohammad, N., Monirul, A. H. (2012). The voluntary disclosure of internet financial reporting (IFR) in an emerging economy: A case of digital Bangladesh. Journal of Asia Business Studies, 6(1), 17-42, https://doi.org/10.1108/15587891211190688 
Peihani, M. (2017). (Rep.). C. Hurst and; Company. Retrieved from http://www.jstor.org/stable/resrep05198

Penno, M. (1997). Information Quality and Voluntary Disclosure. The Accounting Review, 72(2), 275-284. Retrieved from http://www.jstor.org/stable/248556

Phillip, C. S., \& Robert, E. V. (2004). Financial Reporting System Choice and Disclosure Management. The Accounting Review, 79(4), 1181-1203. https://doi.org/10.2308/accr.2004.79.4.1181

Picou, A., \& Rubach, M. (2006). Does Good Governance Matter to Institutional Investors? Evidence from the Enactment of Corporate Governance Guidelines. Journal of Business Ethics, 65(1), 55-67. Retrieved from http://www.jstor.org/stable/25123770

Rensburg, R., \& Botha, E. (2014). Is Integrated Reporting the silver bullet of financial communication? A stakeholder perspective from South Africa. Public Relations Review, 40(2), 144-152. https://doi.org/10.1016/j.pubrev.2013.11.016.

Salama, F. M., \& Putnam, K. (2013). The Impact of Corporate Governance on the Financial Outcomes of Global Diversification. The International Journal of Accounting, 48(3), 364-389. https://doi.org/10.1016/j.intacc.2013.07.003

Salvioni, D (2012). Transparency Culture and Financial Communication (March 1, 2002). Symphonya Emerging Issues in Management. Retrieved from https://ssrn.com/abstract=2577239

Sarapaivanich, N., \& Kotey, B. (2006). The Effect of Financial Information Quality on Ability to Access External Funds and Performance of SMEs in Thailand. Journal of Enterprising Culture, 14(03), 219-239. https://doi.org/10.1142/s0218495806000143

Shaikh, M. (1999). Corporate Employees' Demand for Financial Information: An Empirical Study. Indian Journal of Industrial Relations, 35(2), 145-159. Retrieved from http://www.jstor.org/stable/27767648

Stocken, P., \& Verrecchia, R. (2004). Financial Reporting System Choice and Disclosure Management. The Accounting Review, 79(4), 1181-1203. Retrieved from http://www.jstor.org/stable/4093090

Talmor, E. (1981). Asymmetric Information, Signaling, and Optimal Corporate Financial Decisions. The Journal of Financial and Quantitative Analysis, 16(4), 413-435. https://doi.org/10.2307/2330363

Titman, S., \& Trueman, B. (1986). Information quality and the valuation of new issues. Journal of Accounting and Economics, 8(2), 159-172. https://doi.org/10.1016/0165-4101(86)90016-9

Tsamenyi, M., Cullen, J., \& María González González, J. (2006). Changes in accounting and financial information system in a Spanish electricity company: A new institutional theory analysis. Management Accounting Research, 17(4), 409-432. https://doi.org/10.1016/j.mar.2006.02.002

Van Caneghem, T., \& Van Campenhout, G. (2012). Quantity and quality of information and SME financial structure. Small Business Economics, 39(2), 341-358. Retrieved from http://www.jstor.org/stable/41682802

Vanden, J. (2008). Information Quality and Options. The Review of Financial Studies, 21(6), 2635-2676. Retrieved from http://www.jstor.org/stable/40056895

Wang, S. (2013). Financial Communications: Information Processing, Media Integration, and Ethical Considerations. Stamford, USA: Palgrave Macmillan US

Weetman, P. (2018). Financial reporting in Europe: Prospects for research. European Management Journal, 36(2), 153-160. https://doi.org/10.1016/j.emj.2017.11.002

Wittenberg-Moerman, R. (2008). The role of information asymmetry and financial reporting quality in debt trading: Evidence from the secondary loan market. Journal of Accounting and Economics, 46(2-3), 240-260. https://doi.org/10.1016/j.jacceco.2008.08.001 


\section{Appendix A}

Discriminant analysis

Table 9. Tests of equality of group means

\begin{tabular}{lrrrrr}
\hline & Wilks' Lambda & \multicolumn{1}{c}{ F } & df1 & df2 & \multicolumn{1}{c}{ Sig. } \\
\hline PER &, 991 &, 572 & 1 & 62 &, 452 \\
PBR & 1,000 &, 002 & 1 & 62 &, 965 \\
OP &, 852 & 10,786 & 1 & 62 &, 002 \\
\hline
\end{tabular}

\section{Appendix B}

Separate-Groups Graphs

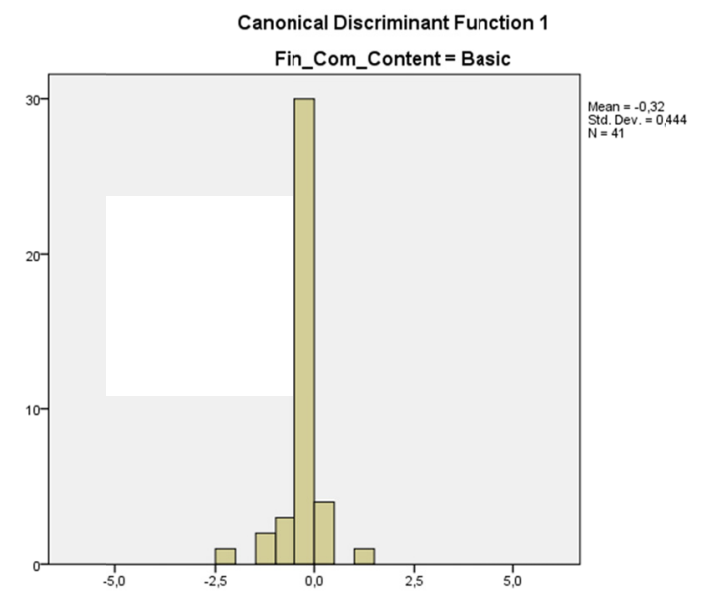

Figure B1. Basic group graph

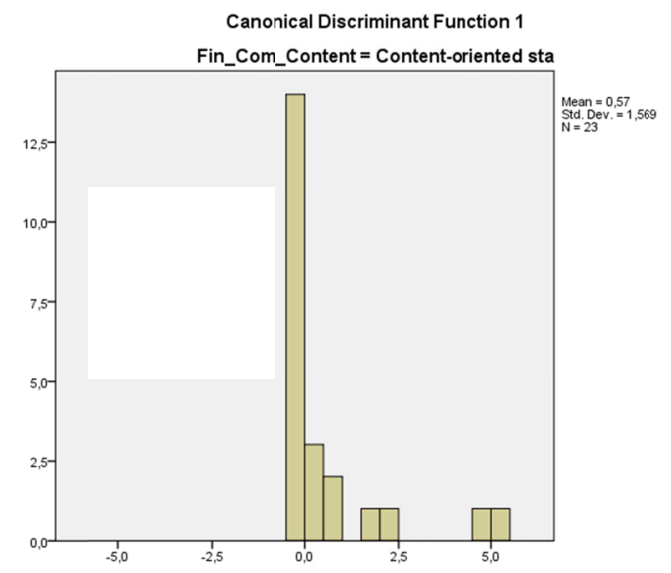

Figure B2. Content-oriented Stakeholders group graph

\section{Copyrights}

Copyright for this article is retained by the author(s), with first publication rights granted to the journal.

This is an open-access article distributed under the terms and conditions of the Creative Commons Attribution license (http://creativecommons.org/licenses/by/4.0/). 